УДК 655.3.021.6:655.3.022.14

\title{
ОСОБЛИВОСТІ ПІДГОТОВКИ ВИТРАТНИХ МАТЕРІАЛІВ ДЛЯ ЦІННИХ ПАПЕРІВ
}

() О. В. Зоренко, к.Т.н., доцент, О. С. Кочемасов, магістр, Ю. С. Кочемасов, магістр, НТУУ «КПІ», О. Ю. Байдак, к.т.н., доцент, ТОВ «Мак Хаус», Київ, Україна

Проанализировано влияние на качество банкнотной продукции характеристик бумаги и краски. Предложены методы и средства оптимальной их подготовки к печати.

The influence of the quality of the product characteristics Banknote paper and ink. Methods and means of preparation for optimal printing.

\section{Постановка проблеми}

Якісне кольоровідтворення, висока роздільна, видільна здатності, стійкість до зовнішніх впливів друкованого зображення будь-якого виду поліграфічної продукції за мінімальних витрат на її виготовлення потребує проведення всебічних технологічних досліджень задля визначення залежностей показників якості від різних чинників, що впливають на технологічний процес [1].

Для виготовлення цінних паперів використовують папір високої якості, який повинен відповідати певним технологічним вимогам: довговічності, стійкості до дії чинників навколишнього середовища, міцності на розрив, згинання тощо. Сучасні захисні друкарські фарби для цінних паперів також мають сукупність друкарсько-технічних властивостей, що визначають їх поведінку в процесі друкування та отримання високоякісного відбитка, а ступінь відповідності даних показників регламентова- ним стандартам та технічним вимогам дозволяє обирати оптимальні режими друкування, засоби підготовки фарби до використання [2].

\section{Аналіз попередніх досліджень}

Для виконання поліграфічного оформлення цінних паперів використовуються як основні так і спеціальні способи друку високий, плоский, глибокий, орловський, металографічній, високий офсетний, ірисовий тощо, так і спеціалізовані за характеристиками папери та фарби.

Для встановлення причин зниження якості друкованого відбитка або неполадки в процесі друкування необхідно встановити властивості основних матеріалів, їх взаємної відповідності та умовам друкування.

Від складу і режиму виготовлення паперу залежать такі основні властивості, що впливають на якість друкованої продукції: стійкість до впливу атмосферних умов друкарського цеху, 
рівномірність розподілу в ньому вологи і міра звільнення від внутрішньої напруги. Покращення даних властивостей є основним завданням підготовки його до друку, що проводиться, як правило, безпосередньо на поліграфічних підприємствах. Адже правильний режим підготовки паперу зменшує його деформацію в процесі друкування, що необхідно для точного суміщення елементів зображення при друкуванні декількома фарбами.

Підготовка паперу до друку складається з розрізання (рулонний папір), акліматизації, звільнення від внутрішньої напруги, підрізування за форматом і транспортування в друкарський цех.

Папір - матеріал гігроскопічний і тому сильно реагує на зміну вологості довкілля, тобто змінює свою вологість відповідно до вологості повітря. Від вологості паперу залежать його друкарсько-технічні, структурні, механічні властивості. При збільшенні вологості знижується жорсткість паперу, збільшується загальна деформація, зменшується механічна міцність. Зменшення механічної міцності, у свою чергу, може привести до вищипування волокон при друкуванні або до руйнування поверхневого шару крейдованого паперу. Знижена вологість робить папір крихким (можуть бути злами в місцях перегинів), призводить до пиління. Від вологості паперу залежить закріплення фарби на відбитках. Вологість паперу змінюється під впливом темпе- ратурного режиму при його зберіганні і транспортуванні [1-3].

\section{Мета роботи}

Дослідження впливу на властивості банкнотного паперу параметрів мікроклімату приміщення для його зберігання i підготовки до друку.

\section{Результати проведених досліджень}

Для проведення експериментальних досліджень було використано офсетний та банкнотний папір для номіналів: 2,

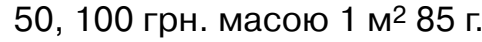

В процесі виготовлення друкованої продукції, зокрема грошових знаків, папір контактує з рідкими матеріалами, що входять до складу друкарських фарб, а також може зазнавати впливу різних рідин, зокрема води.

Підвищення вологості навколишнього середовища або намочування у воді змінює лінійні розміри паперового аркуша. Одна з причин цього - набрякання волокон. При зволоженні рослинні волокна, з яких складається папір, набрякають, внаслідок чого змінюються розміри аркуша.

Ступінь лінійної деформації паперу - це зміна лінійних розмірів аркуша паперу (за довжиною і шириною) під дією зміни вологості навколишнього середовища [2].

Визначення лінійної деформації при зволоженні і висушуванні паперу - визначення лінійних розмірів паперу до і після намокання та висушу- 
вання та розрахунок відносної деформації проводили згідно 3 [4].

Кількісне значення деформації визначали відношенням збільшення розмірів зволоженого аркуша до первинних розмірів сухого й визначали у відсотках.

Отримані результати дослідження зміни лінійної деформації наведено в табл. 1.

Деформація паперу виникає не тільки при його зануренні у воду, а й має місце й при зміні вологості навколишнього середовища.

Визначення вологості паперу - маса паперу до і після висушування і розрахунок вологості проводили згідно [4].

Результати розрахунків дослідженої вологості паперу наведено в табл. 2.

Отже, проведені дослідження свідчать, що банкнотний

папір під дією вологи змінює лінійну деформацію та вологість паперу.

Неоднорідність структури паперу й орієнтація волокон у машинному напрямку є причиною деформації у різних напрямках. Згідно табл. 1 деформація має більшу величину в машинному напрямку, тобто при набряканні кожне волокно більше видовжується, ніж розширюється. Найбільшої деформації зазнає папір із замкнутою структурою, меншої - пористий, у якому через значну кількість пор набрякання менше впливає на розмір аркуша. Звідси необхідно корегувати і контролювати склад паперу за наповнювачем і типом проклейки.

Зміна вмісту вологи в папері при коливанні атмосферних умов у цехах поліграфічного підприємства спричинює де-

Таблиця 1

Лінійна деформація паперу після зволоження та висушування

\begin{tabular}{|c|l|c|c|}
\hline \multirow{2}{*}{$\begin{array}{c}\text { № } \\
\text { п/4 }\end{array}$} & \multicolumn{1}{|c|}{ Показники } & \multicolumn{2}{|c|}{ Направлення відливу паперу } \\
\cline { 3 - 4 } & & машинне & поперечне \\
\hline 1 & Першопочаткова довжина контрольних ліній, мм & 50 & 50 \\
\hline 2 & Довжина контрольних ліній після зволоження, мм & 50,2 & 50,1 \\
\hline 3 & Лінійна деформація паперу після зволоження, \% & $-0,4$ & $-0,2$ \\
\hline 4 & Довжина контрольних ліній після висушування, мм & 49,8 & 49,9 \\
\hline 5 & Лінійна деформація паперу після висушування, \% & 0,4 & 0,2 \\
\hline
\end{tabular}

Таблиця 2

Вологість банкнотного паперу

\begin{tabular}{|c|l|c|}
\hline № п/ч & \multicolumn{1}{|c|}{ Показники } & Визначення \\
\hline 1 & Маса тигля, г & 5 \\
\hline 2 & Маса тигля з наважкою до висушування, г & 5,052 \\
\hline 3 & Маса тигля з наважкою після висушування, г & 5,05 \\
\hline 4 & Вологість паперу, \% & 3,85 \\
\hline
\end{tabular}


формацію паперу. Коли в цех потрапляє палета з папером, що має іншу температуру, між ним і середовищем починається обмін вологою, що особливо характерно для зимової пори. Папір, холодніший за повітря, є відносно більш сухим і тому починає всотувати вологу. Краї аркуша всотують вологу, набрякають, стають хвилястими, утворюють зморшки, що утруднює суміщення фарб.

Для уникнення деформації банкнотного паперу при зволоженні (відносна вологість паперу складає 2-6 \%, в дослідженні (табл. 2) - 3,85 \%), статичної електрики та зменшення міцності, рекомендовано акліматизувати папір перед його використанням (табл. 3).

Акліматизацію паперу також проводять з метою: вирівнювання вологості по всій площі аркуша, приведення вологості паперу до вологості робочого приміщення, приведення температури паперу до температури довкілля, зняття внутрішньої напруги між волокнами після розмотування рулону паперу. Папір акліматизують в спеціальних приміщеннях або аклімати- заційних камерах, де папір маленькими пачками підвішують на транспортер, який рухається. Знизу подається кондиційоване (певної температури і вологості) повітря. Знаходячись у вільному підвішеному стані, аркуші паперу звільняються від внутрішньої напруги, яка розвивається в рулонному папері внаслідок сильного натягнення паперової стрічки, набувають вологості і температури, які відповідають температурі і вологості цеху [5]. Час вистоювання, після якого папір може бути запущений у виробництво, залежить від об'єму стосу паперу, різниці температур у цеху та в середині стосу [2].

Для банкнотного паперу дуже важливо збереження заданих показників температури і вологості. Очевидно, що найбільш складною проблемою $€$ підтримка вологості, особливо в холодний період року.

Порушення режиму вологості в умовах цехів і комор паперу іноді призводить до негативних результатів: банкнотний папір в сухому приміщенні може зменшуватися в розмірах, що ускладнює процес друкування;

Таблиця 3

Рекомендована тривалість акліматизації

\begin{tabular}{|c|c|c|c|c|c|c|c|}
\hline \multirow{2}{*}{$\begin{array}{c}\text { № } \\
\text { п/п }\end{array}$} & \multirow{2}{*}{$\begin{array}{c}\text { Об'єм } \\
\text { стосу, }{ }^{3}\end{array}$} & \multicolumn{6}{|c|}{ Тривалість акліматизації при різниці між трукарського цехуі } \\
\cline { 3 - 8 } & & $10^{\circ} \mathrm{C}$ & $15^{\circ} \mathrm{C}$ & $20^{\circ} \mathrm{C}$ & $25^{\circ} \mathrm{C}$ & $30^{\circ} \mathrm{C}$ & $35^{\circ} \mathrm{C}$ \\
\hline 1 & 0,2 & 4 & 7 & 9 & 15 & 21 & 28 \\
\hline 2 & 0,4 & 7 & 12 & 17 & 26 & 36 & 41 \\
\hline 3 & 0,6 & 9 & 15 & 20 & 31 & 42 & 55 \\
\hline 4 & 1,0 & 12 & 18 & 23 & 33 & 46 & 63 \\
\hline 5 & 2,0 & 13 & 19 & 24 & 35 & 49 & 66 \\
\hline
\end{tabular}


сухий папір може накопичувати статичну електрику, $€$ більш крихким, менш міцним, частіше рветься; сухе повітря викликає короблення паперу при збережені в стосі, оскільки края паперу сохнуть швидше, ніж середина аркуша. Аналогічні явища відбуваються і при великій різниці температур паперу та повітря в коморах і цехах.

Комори зазвичай облаштовані одним кондиціонером, але його не достатньо для забезпечення постійного мікроклімату в приміщенні. Тому встановлення системи вентиляції і кондиціонуванняна на базі припливно-витяжних агрегатів з рекуперацією теплаVR 300 ECV дозволяє економити до 75 кВт електроенергії на нагріванні припливного повітря. Встановлення припливно-витяжного агрегату з рекуперацію тепла дозволяє забезпечити стабільні показники мікроклімату в коморах паперу, що в свою чергу, дозволить зменшити витрати паперу на друк та приладку.

За результатами дослідження рекомендовано проводити щоденний контроль параметрів мікроклімату за допомогою автономного термогігрометру та заміри вологості в стосі банкнотного паперу.

Для забезпечення високої якості друкування пропонується використати асортимент допоміжних матеріалів та технологічних добавок, що створять стабільні умови друкарського процесу і дозволять корегувати технологічні властивості фарб.

Основною проблемою є зниження в'язкості фарби без збільшення часу її висихання, втрати контрасту і глянцю. Тому рекомендовано застосувати гель для зниження в'язкості Colorthix, що дозволить більш рівномірно накочувати фарбу і друкувати на максимальній швидкості, одночасно запобігаючи заломленню та скручуванню паперу на приймальному пристрої.

Добавка у друкарську фарбу Color Stabil поліпшить її плин і усуне скупчення фарби на валиках у місцях з невеликим її зняттям, а також оголення дукторних, розкочувальних, накочувальних гумових валиків.

\section{Висновки}

Проведено дослідження лінійної деформації та вологості банкнотного паперу за умов невисокої вологості і обмеженого повітряного обміну в коморах і цехах виробництва.

При багатофарбовому друці з непередбаченими зупинками, для забезпечення якості відбитків рекомендовано добавки у друкарську фарбу Color Stabil та Colorthix, що сприятимуть зниженню заломлення та скручування паперу.

Запропоновано методи і засоби контролю параметрів мікроклімату в коморах паперу та вологості в стосі банкнотного паперу. 
1. Величко О. М. Опрацювання інформаційного потоку взаємодією елементів друкарського контакту / О. М. Величко. - Київ : ВПЦ «Київський університет», 2005. - 264 с. 2. Поліграфічні матеріали / Ю. Ц. Жидецький, О.В.Лазаренко, Н. Д. Лотошинська та ін. - Підручник / За заг. редакцією д.т.н., проф. Е. Т. Лазаренка. - Л. : Афіша, 2001. - 328 с. 3. Мельников О. В. Технологія плоского офсетного друку / Під редакцією д.т.н., проф. Лазаренка Е. Т. - Львів : УАД. - 2007. - 392 с. 4. Анісімова С. В. Лабораторний практикум з поліграфічного матеріалознавства / С. В. Анісімова, Л. М. Олексій, З. Г. Токарчик, В. В. Шибанов. - Навч. посібник. - Л. : Афіша, 2001. - 184 с. 5. Подготовка бумаги к офсетной печати [Електронний ресурс]. - Режим доступу : http:// www.promopoligraph.ru.

1. Velychko O. M. Opratsiuvannia informatsiinoho potoku vzaiemodiieiu elementiv drukarskoho kontaktu / O. M. Velychko. - Kyiv : VPTs «Kyivskyi universytet», 2005. - 264 s. 2. Polihrafichni materialy / lu. Ts. Zhydetskyi, O. V. Lazarenko, N. D. Lotoshynska ta in. - Pidruchnyk / Za zah. redaktsiieiu d.t.n., prof. E. T. Lazarenka. - L. : Afisha, 2001. - 328 s. 3. Melnykov O. V. Tekhnolohiia ploskoho ofsetnoho druku / Pid redaktsiieiu d.t.n., prof. Lazarenka E. T. - Lviv : UAD. - 2007. - 392 s. 4. Anisimova S. V. Laboratornyi praktykum z polihrafichnoho materialoznavstva / S. V. Anisimova, L. M. Oleksii, Z. H. Tokarchyk, V. V. Shybanov. - Navch. posibnyk. - L. : Afisha, 2001. 184 s. 5. Podgotovka bumagi k ofsetnoj pechati [Elektronnyi resurs]. - Rezhym dostupu : http:// www.promopoligraph.ru.

Рецензент - О. М. Величко, д.т.н., професор, НТУУ «КП|»

Надійшла до редакції 11.12.13 